\title{
Preparation of Zirconium Carbide-Zirconium Silicide Composite Powders by Solid Reaction of $\mathrm{Zr}$ and SiC Powders
}

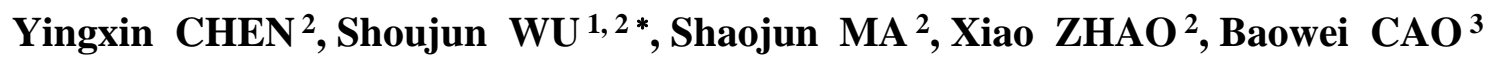 \\ ${ }^{1}$ Key Laboratory of Agricultural Soil and Water Engineering in Arid and Semiarid Areas, Ministry of Education, Northwest \\ A\&F University, Yangling Shaanxi, 712100, People's Republic of China \\ ${ }^{2}$ College of Water Resources and Architectural Engineering, Northwest A\&F University, Yangling Shaanxi, 712100, \\ People's Republic of China \\ ${ }^{3}$ School of Chemistry and Chemical Engineering, Yulin University, Yulin Shaanxi, 719000, People's Republic of China
}

crossref http://dx.doi.org/10.5755/j01.ms.26.3.21733

Received 29 September 2018; accepted 06 January 2019

\begin{abstract}
In the present work, zirconium carbide-zirconium silicide composite powders were prepared by solid reaction using $\mathrm{Zr}$ and $\mathrm{SiC}$ powders as reactants. Scanning electron microscopy (SEM) and X-ray diffraction (XRD) results showed that, after treatment at $800{ }^{\circ} \mathrm{C}$, the produced zirconium carbide-zirconium silicide diffusion layer was very thin and mainly consisted of $\mathrm{ZrC}$ and $\mathrm{ZrSi}_{2}$. After treatment above $900{ }^{\circ} \mathrm{C}$, the produced phases were mainly consisted of $\mathrm{ZrC}$ and $\mathrm{ZrSi}_{2}$, plus less $\mathrm{ZrSi}$.

Keywords: zrconium carbide, zirconium silicide, composite powder, solid reaction.
\end{abstract}

\section{INTRODUCTION}

$\mathrm{ZrC}$ is attracting more and more attention for applications in thermal protection systems for hypersonic flight, atmospheric re-entry and rocket propulsion due to its high melting points $\left(3540{ }^{\circ} \mathrm{C}\right)$, low densities $\left(6.7 \mathrm{~g} / \mathrm{cm}^{3}\right)$ and excellent wear resistance $[1,2]$. However, the application of $\mathrm{ZrC}$ ceramics in single phase is quite limited due to their low oxidation resistance $[3,4]$, besides sintering of $\mathrm{ZrC}$ is difficult due to its covalent nature and high melting point.

Research has confirmed that $\mathrm{ZrSi}_{2}$ can significantly lower the onset densification temperature of $\mathrm{ZrB}_{2}$ ceramics [5]. Addition of $\mathrm{ZrSi}_{2}$ can also improve the oxidation and ablation resistance for $\mathrm{ZrB}_{2}-\mathrm{SiC}$ and $\mathrm{SiC}$ coating [6, 7]. It also has been demonstrated that $\mathrm{ZrC}-\mathrm{ZrSi}_{2}-\mathrm{SiC}$ coating possesses improved oxidation and thermal shock resistance [8].

Compared with blended powders, composite powders are more favorable to improving densification kinetics during sintering and thus improving the density and mechanical properties of sintered body $[9,10]$. Therefore, $\mathrm{ZrC}-\mathrm{ZrSi}_{2}$ composite ceramic powders with fine and homogeneous structure is very important to act as precursors of composites. However, reports on the synthesis of $\mathrm{ZrC}-\mathrm{ZrSi}_{2}$ composite ceramic powders are lacking.

Earlier works have demonstrated that $\mathrm{ZrC}-\mathrm{ZrB}_{2}$, TiC$\mathrm{TiB}_{-} \mathrm{TiB}_{2}$ composite ceramic powders can be prepared by solid reaction between powder of $\mathrm{Zr}$ or $\mathrm{Ti}$ and $\mathrm{B}_{4} \mathrm{C}[11,12]$. High vacuum heat treatment between 700 to $850{ }^{\circ} \mathrm{C}$ for $30 \mathrm{~min}, \mathrm{Zr}$ film deposited on $\mathrm{SiC}$ substrate reacts and forms $\mathrm{ZrC}$ and $\mathrm{Zr}$ silicides $\left(\mathrm{Zr}_{2} \mathrm{Si}, \mathrm{ZrSi}_{2}\right.$ and $\left.\mathrm{Zr}_{5} \mathrm{Si}_{3}\right)$ [13]. The work conducted by Bhanumurthy et al., compacted $\mathrm{SiC}$ powder filled in $\mathrm{Zr}$ cup and compressed to make sure intimate contact were used to study the diffusion of them. It has confirmed that heat treatment at 1100 to $1300{ }^{\circ} \mathrm{C}$ in argon for $144 \mathrm{~h}$, leads to in-situ solid reaction between $\mathrm{Zr}$ and $\mathrm{SiC}$ and formation of $\mathrm{Zr}_{5} \mathrm{Si}_{3} \mathrm{C}, \mathrm{Zr}_{2} \mathrm{Si}$ and $\mathrm{ZrC}$. However, it is also reported experiment using small pieces of $\mathrm{Zr}$ and $\mathrm{SiC}$ powder were not successful [14]. Therefore, it is necessary to study whether solid reaction can occur between loose powder of $\mathrm{Zr}$ and $\mathrm{SiC}$ and to confirm the produced products.

In the present work, the solid reaction between $\mathrm{Zr}$ and $\mathrm{SiC}$ powder mixtures under low pressures and preparation of zirconium carbide-zirconium silicide composite powders by solid reaction of $\mathrm{Zr}$ and $\mathrm{SiC}$ powders was studied.

\section{EXPERIMENTAL PROCEDURE}

Zirconium ( $\mathrm{Zr}$ ) powders (ABCRTM, $99.9 \%$ purity, with an average particle size of to $1-5 \mu \mathrm{m})$ and silicon carbide powders (SiC) (BeiJing TopVendor Science \&Technology CO., Ltd, $99.9 \%$, with an average particle size of about $0.5 \mu \mathrm{m}$ ) are used as initial powders. It has been demonstrated that the produced phases by reactive diffusion between $\mathrm{Zr}$ and $\mathrm{Si}$ was mainly in $\mathrm{ZrSi}_{2}$ plus less $\mathrm{ZrSi}$ [15]. In order to make $\mathrm{SiC}$ completely reaction consumed, the molar ratio of $\mathrm{Zr}$ to $\mathrm{SiC}$ should be slightly smaller than $3: 1$. The mixture composition with molar ratio of $\mathrm{Zr}: \mathrm{SiC}$ of $3: 1$ was used. The powders mixture treated at $800{ }^{\circ} \mathrm{C}$ to $1000{ }^{\circ} \mathrm{C}$ for different times.

The phase composition was identified by using X-ray diffraction (XRD, BRUKER, D8 ADVANCE A25 X). XRD analysis was operated at $40 \mathrm{kV}$ and $40 \mathrm{~mA}$. Step scans were taken in the range of $2 \theta=30-80^{\circ}$ with a 0.02 -step, $0.1^{\circ} \mathrm{s}^{-1}$ scan speed and a $2 \mathrm{~s}$ exposure. The microstructure of the powders was characterized by scanning electron microscopy (SEM, S-4800, Hitachi) equipped with an Energy Dispersive Spectrometer (EDS).

\footnotetext{
* Corresponding author. Tel.: +86-29-87082902; fax: 86-29-87082901.

E-mail address: shoujun_wu@163.com $(\mathrm{S} . \mathrm{Wu})$
} 


\section{RESULTS AND DISCUSSION}

Fig. 1 shows the XRD patterns of the heat-treated mixture of $\mathrm{Zr}$ and $\mathrm{SiC}$ powders. Peaks of $\mathrm{ZrC}$ and $\mathrm{ZrSi}_{2}$ are detected for all of the treated powder mixtures, which confirming formation of zirconium carbide-zirconium silicide composite powders.

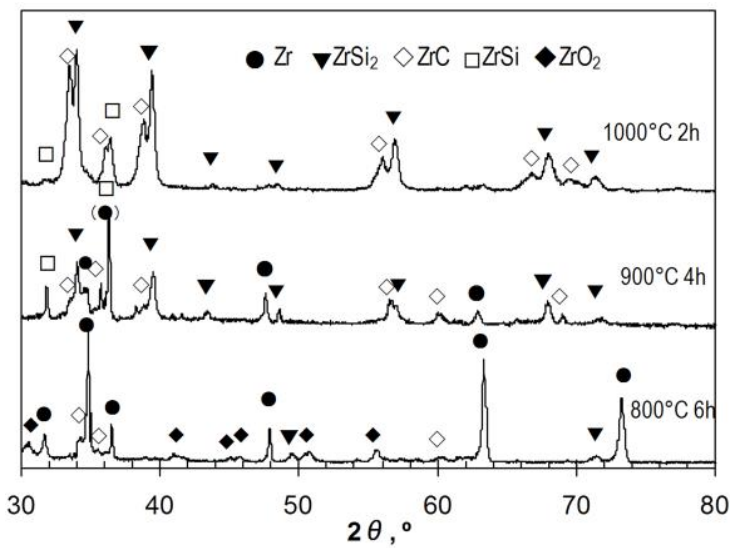

Fig. 1. XRD patterns of the heat-treated mixture of $\mathrm{Zr}$ and $\mathrm{SiC}$ powders

After treatment at $800^{\circ} \mathrm{C}$, evident peaks corresponding to $\mathrm{Zr}$ and very weak peaks corresponding to $\mathrm{ZrC}$ and $\mathrm{ZrSi}_{2}$ suggest that the zirconium carbide-zirconium silicide layer is very thin and the reaction is incomplete. It also should be noted that peaks corresponding to $\mathrm{ZrO}_{2}$ are detected. After treatment at $900{ }^{\circ} \mathrm{C}$, peaks corresponding to $\mathrm{Zr}, \mathrm{ZrC}, \mathrm{ZrSi}$ and $\mathrm{ZrSi}_{2}$ are detected. However, no peaks of $\mathrm{ZrO}_{2}$ are detected. After treatment at $1000{ }^{\circ} \mathrm{C}$, the produced phases are mainly in $\mathrm{ZrC}$ and $\mathrm{ZrSi}_{2}$, less $\mathrm{ZrSi}$ is detected. Therefore, the above results indicate that increasing the treatment temperatures facilitates preferentially formed $\mathrm{ZrO}_{2}$ further react and depleted. Moreover, with treatment temperature increasing, it appeared that the intensity of $\mathrm{ZrSi}_{2}$ and $\mathrm{ZrC}$ are significantly increased, the same to the intensity of $\mathrm{ZrSi}_{2}$ to that of $\mathrm{ZrC}$. However, the intensity of $\mathrm{ZrSi}$ to that of $\mathrm{ZrC}$ decreases with treatment temperature increasing. After treatment at $1000 \mathrm{C}$, the produced phases contain relatively more balanced amounts of $\mathrm{ZrSi}_{2}$ and $\mathrm{ZrC}$. Therefore, treatment at $1000{ }^{\circ} \mathrm{C}$ for $2 \mathrm{~h}$ is suitable for obtaining $\mathrm{ZrC}$ $\mathrm{ZrSi}_{2}$ composite powders for the present used powder mixture.

The above results are similar to those observed by E.G. Njoroge et al. [13] In their work, it is confirmed $\mathrm{ZrO}_{2}$ was detected by XRD at the interface of $\mathrm{Zr}$ films deposition on $\mathrm{SiC}$ after respectively thermal annealing at 700, 760 and $800{ }^{\circ} \mathrm{C}$, while it was undetectable after thermal annealing at $850{ }^{\circ} \mathrm{C}$. It should be noted that, the produced phases between the $\mathrm{Zr}$ and $\mathrm{SiC}$ in this work are different to those reported by Bhanumurthy et al. [14] In their work, after treatment at $1100{ }^{\circ} \mathrm{C}$ for $144 \mathrm{~h}$, it is confirmed $\mathrm{Zr}_{5} \mathrm{Si}_{3} \mathrm{C}$ was also detected by XRD and EPMA. The effective Gibbs energy of formation of the $\mathrm{Zr}_{5} \mathrm{Si}_{3} \mathrm{C}$ is considerably less than all the other phases of zirconium carbides and zirconium silicides, therefore it cannot be the initial phases to form [13]. The treatment time the present work (less than $6 \mathrm{~h}$ ) and that of the work conducted by E.G. Njoroge et al. [13] was much less than that of the work conducted by Bhanumurthy et al., beside the temperature is lower. The condition is not enough to form $\mathrm{Zr}_{5} \mathrm{Si}_{3} \mathrm{C}$ and $\mathrm{Zr}_{5} \mathrm{Si}_{3}[13,16]$. Therefore, the formed phases in the present work are $\mathrm{ZrC}, \mathrm{ZrSi}$ and $\mathrm{ZrSi}_{2}$.

Fig. 2 shows the SEM micrographs (top) and EDS spectra (bottom) of the as-received $\mathrm{SiC}$ powders and the treated mixtures.

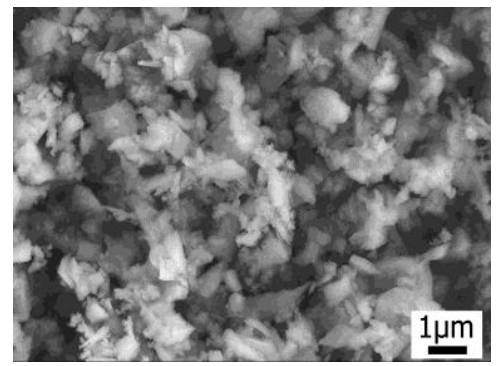

a

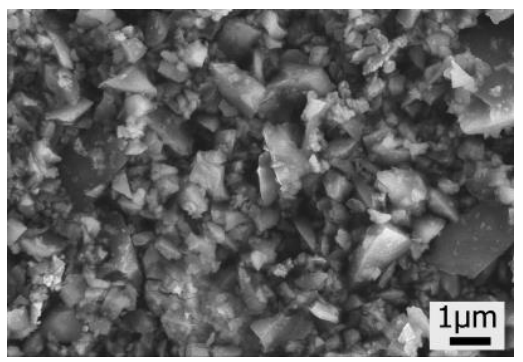

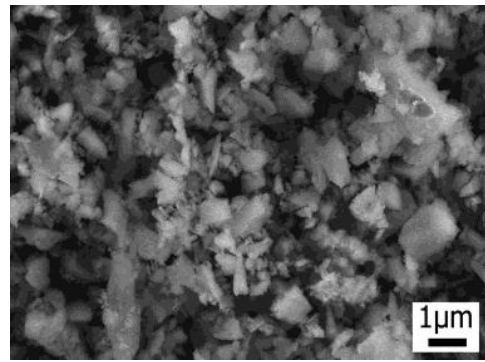

e

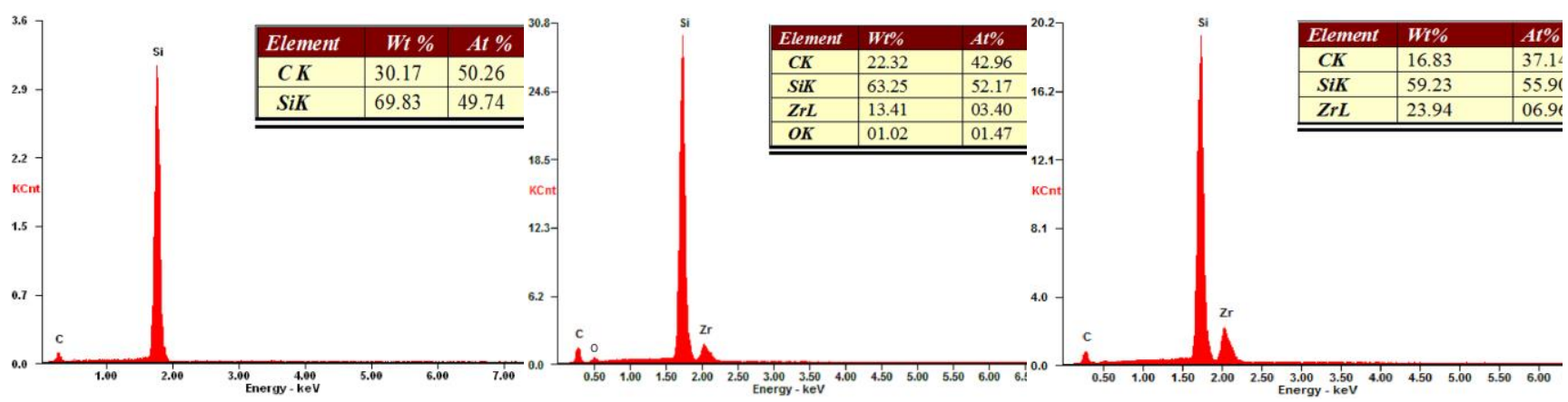

b

f

Fig. 2. SEM micrographs (top) and EDS spectra (bottom) of the: a, b-as-received SiC powders; $\mathrm{c}$, d-the treated mixture: at $800{ }^{\circ} \mathrm{C}$ for $6 \mathrm{~h} ; \mathrm{e}, \mathrm{f}-$ at $1000^{\circ} \mathrm{C}$ for 2 
From the EDS results of $800{ }^{\circ} \mathrm{C}$ treated mixture, the detected atomic percent of $\mathrm{C}, \mathrm{Si}, \mathrm{Zr}$ and $\mathrm{O}$ is respectively $42.96,52.17,3.40$ and 1.47, which also suggests the formed diffusion layer is very thin. After treatment at $1000{ }^{\circ} \mathrm{C}$ for $2 \mathrm{~h}$, the detected atomic percent of $\mathrm{C}, \mathrm{Si}$ and $\mathrm{Zr}$ is respectively $37.14,55.9$ and 6.96 , which was relatively more balanced than that of treated at other temperatures. Therefore, treatment at $1000{ }^{\circ} \mathrm{C}$ for $2 \mathrm{~h}$ is suitable for preparing $\mathrm{ZrC}-\mathrm{ZrSi}_{2}$ composite powders using the present powders mixture.

As the powders mixture is sealed in the air, adsorption of oxygen is inevitable for the fine powders. Since $\mathrm{Zr}$ is more prone to oxidation than $\mathrm{SiC}[13,17]$ and the adsorbed oxygen is very limited, the possible oxidation product is $\mathrm{ZrO}_{2}$. On the other hand, $\mathrm{ZrO}_{2}$ might potentially further depleted due to reaction with $\mathrm{SiC}$ and $\mathrm{Zr}$ [14]. Possible reactions during the treatment are listed as follows:

$$
\begin{aligned}
& \mathrm{ZrO}_{2}+3 \mathrm{SiC}+3 \mathrm{Zr} \rightarrow 3 \mathrm{ZrSi}+\mathrm{ZrC}+2 \mathrm{CO} \\
& \mathrm{ZrO}_{2}+4 \mathrm{SiC}+3 \mathrm{Zr} \rightarrow 2 \mathrm{ZrSi} 2+2 \mathrm{ZrC}+2 \mathrm{CO} \\
& \mathrm{ZrO}_{2}+2 \mathrm{SiC}+\mathrm{Zr} \rightarrow 2 \mathrm{ZrSi}+2 \mathrm{CO} \\
& \mathrm{ZrO}_{2}+2 \mathrm{SiC} \rightarrow \mathrm{ZrSi}_{2}+2 \mathrm{CO} \\
& 3 \mathrm{Zr}+2 \mathrm{SiC} \rightarrow \mathrm{ZrSi}_{2}+2 \mathrm{ZrC} \\
& 2 \mathrm{Zr}+\mathrm{SiC} \rightarrow \mathrm{ZrSi}+\mathrm{ZrC} \\
& 3 \mathrm{ZrSi}+\mathrm{SiC} \rightarrow 2 \mathrm{ZrSi}_{2}+\mathrm{ZrC}
\end{aligned}
$$

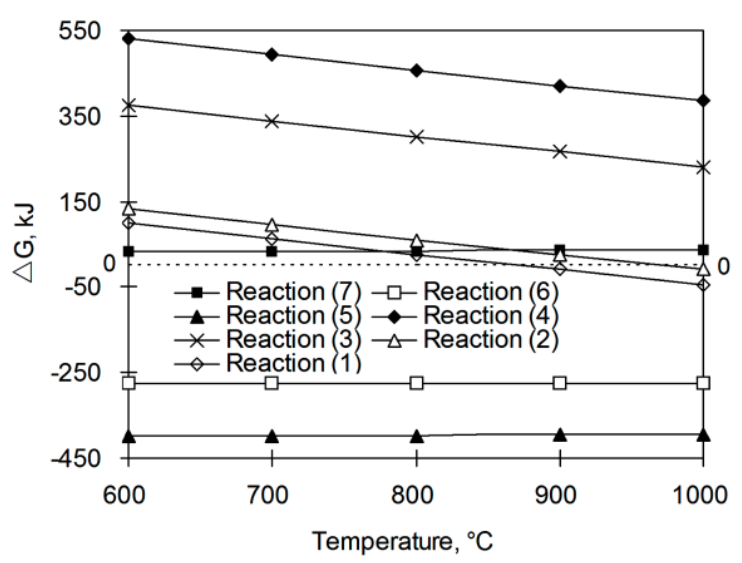

Fig. 3. Variation of Gibbs free energy of the possible reactions with temperatures

Fig. 3 shows variation of the Gibbs free energies $(\Delta G)$ of the above reactions as a function of temperatures. It can be seen that over the calculated temperature ranges, Eq. 3, Eq. 4 and Eq. 7 are thermodynamically unfavorable $(\Delta G>0)$, while Eq. 5 and Eq. 6 are thermodynamically favorable $(\Delta G<0)$. It is supposed that Eq. 5 and Eq. 6 is coinstantaneous, $\mathrm{ZrSi}_{2}, \mathrm{ZrSi}$ and $\mathrm{ZrC}$ can simultaneously formed, though the Gibbs free energies $(\Delta G)$ of Eq. 5 are lower. The Gibbs free energies $(\Delta G)$ of Eq. 2 are positive, except at $1000^{\circ} \mathrm{C}$. The Gibbs free energies $(\Delta G)$ of Eq. 1 are negative above $850{ }^{\circ} \mathrm{C}$, while positive below $850^{\circ} \mathrm{C}$. Therefore, the formed $\mathrm{ZrO}_{2}$ might further reaction to form $\mathrm{ZrSi}$ and $\mathrm{ZrC}$ above $900^{\circ} \mathrm{C}$, and thus no peaks of $\mathrm{ZrO}_{2}$ are detected by XRD for those after treatment above $900{ }^{\circ} \mathrm{C}$. And the formed products and their contents proportion vary with the proceeding temperatures.

\section{CONCLUSIONS}

Zirconium carbide-zirconium silicide composite powders can be prepared by solid reaction using $\mathrm{Zr}$ and $\mathrm{SiC}$ powders. The phase composition and their contents proportion of the formed phases vary with the reaction temperatures. After treatment at $800{ }^{\circ} \mathrm{C}$, the produced zirconium carbide-zirconium silicide diffusion layer is very thin and mainly consists of $\mathrm{ZrC}$ and $\mathrm{ZrSi}_{2}$. After treatment above $900{ }^{\circ} \mathrm{C}$, the produced phases are mainly consisted of $\mathrm{ZrC}$ and $\mathrm{ZrSi}_{2}$, plus small amount of $\mathrm{ZrSi}$. Thermodynamics analysis and experimental results indicate powders mixture with the molar ratio of $\mathrm{Zr}$ to $\mathrm{Si}$ of $3: 1$ and treatment at $1000^{\circ} \mathrm{C}$ for $2 \mathrm{~h}$ are suitable to make the $\mathrm{Zr}$ and $\mathrm{SiC}$ completely reacted to form $\mathrm{ZrC}-\mathrm{ZrSi}_{2}$ composite powders.

\section{Acknowledgments}

The authors gratefully acknowledge the financial support from the fund of the Creative Research Foundation of Science and Technology on Thermostructural Composite Materials Laboratory (6142911020105).

\section{REFERENCES}

1. Monteverde, F., Bellosi, A., Scatteia, L. Processing and Properties of Ultra-high Temperature Ceramics for Space Applications Materials Science Enginering A 485 (1) 2008: pp. $415-421$. https://doi.org/10.1016/j.msea.2007.08.054

2. Chamberlain, A.L., Fahrenholtz, W.G., Hilmas, G.E. Pressureless Sintering of Zirconium Biboride Journal of the American Ceramic Society 89 (2) 2006: pp. 450-456. https://doi.org/10.1111/j.1551-2916.2005.00739.x

3. Shimada, S. A thermoanalytical Study on The Oxidation of $\mathrm{ZrC}$ and HfC Powders with Formation of Carbon Solid State Ionics 149 (3-4) 2002: pp. 319-326. https://doi.org/10.1016/S0167-2738(02)00180-7

4. Gasparrini, C., Podor, R., Horlait, D., Chater, R., Lee, W.E. Zirconium Carbide Oxidation: Maltese Cross Formation and Interface Characterization Oxidation of Metals 88 (3-4) 2017: pp. 509-519. https://doi.org/10.1007/s11085-016-9672-6

5. Guo, S.Q., Kagawa, Y., Nishimura, T. Mechanical Behavior of Two-step Hot-pressed $\mathrm{ZrB}_{2}$-based Composites with $\mathrm{ZrSi}_{2}$ Journal of the European Ceramic Society 29 (4) 2009: pp. 509-519. https://doi.org/10.1016/j.jeurceramsoc.2008.06.037

6. Grigoriev, O.N., Galanov, B. A., Lavrenko, V.A., Panasyuk, A.D., Ivanov, S.M., $\quad$ Koroteev, A.V., Nickel, K.G. Oxidation of $\mathrm{ZrB}_{2}-\mathrm{SiC}-\mathrm{ZrSi}_{2}$ Ceramics in Oxygen Journal of the European Ceramic Society 30 (11) 2010: pp. $2397-2405$. https://doi.org/10.1016/j.jeurceramsoc.2010.03.016

7. Wei, W.C.J., Wu, T.M. Oxidation of Carbon/Carbon Composite Coated with $\mathrm{SiC}-\left(\mathrm{SiZrSi}_{2}\right)-\mathrm{ZrSi}_{2}$ Carbon 32 (4) 1994: pp. $605-613$. https://doi.org/10.1016/0008-6223(94)90079-5

8. Hu, M.H., Li, K.Z., Li, H.J., Wang, B., Ma, H.L. Double Layer $\mathrm{ZrSi}_{2}-\mathrm{ZrC}-\mathrm{SiC} / \mathrm{SiC}$ Oxidation Protective Coating for Carbon/Carbon Composites Surface Engineering 31 (5) 2015: pp. $335-341$ https://doi.org/10.1179/1743294414Y.0000000428

9. Yang, Y., Wang, Y., Zhao, Y., Tian, W., He, J.Q., Bian, H.M. Ultrafine Grained Bulk Ceramic Composites 
Consolidated from Nanostructured Composite Powders by Pressureless Sintering Powder Metallurgy $53(4)$ 2013: pp. $336-339$.

https://doi.org/10.1179/174329009X409561

10. Chmielewski, M., Pietrzak, K., Włosiński, W. Properties of Sintered $\mathrm{Al}_{2} \mathrm{O}_{3}-\mathrm{Cr}$ Composites Depending on the Method of Preparation of the Powder Mixture Science of Sintering 38 (3) 2006: pp. 231-238. https://doi.org/10.2298/SOS0603231C

11. Wu, S.J., Wang, Y.G., Fei, Y.L., Yang, Y., Guo, Q. Synthesis of TiC-TiB-TiB 2 Composite Powders by Solid Reaction of Powders Canadian Metallurgical Quarterly 55 (2) 2016: pp. $173-176$.

https://doi.org/10.1080/00084433.2016.1167321

12. Wu, S.J., Wang, Y.G., Gui, D.M. Synthesis of $\mathrm{ZrC}-\mathrm{ZrB}_{2}$ Composite Powders by PIRAC Method Ceramic Transactions 248 2014: pp. 541-545. https://doi.org/10.1002/9781118932995.ch62

13. Njoroge, E.G., Theron, C.C., Hlatshwayo, T.T., Malherbe, J.B. Surface and Interface Reaction Analysis of Zr
Films Deposited on 6H-SiC after Thermal Annealing $R S C$ Advances 6 (72) 2016: pp. 68292-68301.

https://doi.org/10.1039/C6RA13119K

14. Bhanumurthy, K., Schmid-Fetzer, R. Interface Reactions between $\mathrm{SiC} / \mathrm{Zr}$ and Development of Zirconium Base Composites by In-situ Solid State Reactions Scripta Materialia 45 (5) 2001: pp. 547-553. https://doi.org/10.1016/S1359-6462(01)01057-0

15. Roy, S., Paul, A. Growth of Hafnium and Zirconium Silicides by Reactive Diffusion Materials Chemistry and Physics 143 (3) 2014: pp. 1309-1314.

https://doi.org/10.1016/j.matchemphys.2013.11.039

16. Wang, Y.Z., Carim, A.H. Ternary Phase Equilibria in the ZrSi-C System Journal of the American Ceramic Society 78 (3) 1995: pp. 662-666. https://doi.org/ 10.1111/j.1151-2916.1995.tb08229.x

17. Yoo, H.I., Park, S.H. Experimental Verification of a Kinetic Model of Zr-Oxidation Journal of the Korean Ceramic Society 43 (11) 2006: pp. 724-727. https://doi.org/10.4191/KCERS.2006.43.11.724 